пізнавально-творчих якостей студентів і старшокласників в евристичному навчанні. Педагогічні науки: теорія, історія, інноваційні технології. 2016. №2 (56). С.6477.

3. Birgel F., Olsen-Fazi A., Plotnicov L., Rosenthal J., Eckstein J., Me Keachie W. Teaching Evaluations // AAUP: Teaching Evaluations : Publication and Research. URL: http: // www. aaup.org / AAUP / pubsres / academe / 2004 / JF / LTE / birg.htm.

4. Light Richard J. Making the most of the college. Students speak their minds. Cambr., Mass., LND.: Harvard University press, 2001. 242 p.

5. Livingston I.D. Standards, national: Monitoring / International Encyclopedia of Education. Oxford: Pergamon Press, 1985. P.4786-4791.

6. Livingston S.A., Zieky M.J. Passing scores: a manual for setting standards of performance on educational and occupational tests. Princeton, NJ: Educational Testing Service, 1982. P.12.

\section{REFERENCES}

1. Humeniuk, V.V. \& Naumchuk, I.A. (2005). Naukovometodychna robota $\mathrm{z}$ pedahohichnymy kadramy [Scientific and methodical work with pedagogical staff]. KamianetsPodilskyi, 160p. [in Ukrainian].

2.Lazariev, M.O.(2016). Diahnostka samorealizatsiipiznavalnotvorchikh yakostei sudentiv i starshoklasnykiv v evrestychnomu navchanni [Diagnosis of self-realization of cognitive and creative qualities of students and high school students in heuristic learning]. Pedagogical sciences: theory, history and innovative technologies. No. 2(56),pp. 64-77. [inUkrainian].

3. Birgel, F., Olsen-Fazi, A., Plotnicov, L., Rosenthal, J., Eckstein, J., Me Keachie W. (2004). Teaching Evaluations. AAUP : Teaching Evaluations : Publication and Research. Available at: http: // www. aaup.org / AAUP / pubsres / academe / 2004 / JF / LTE / birg.htm. [in English].

4. Light Richard J. (2001). Making the most of the college. Students speak their minds. Cambr., Mass., LND.: Harvard University press. 242 p. [in English].

5. Livingston, I.D. (1985). Standards, national: Monitoring. International Encyclopedia of Education. Oxford: Pergamon Press. pp.4786-4791. [in English].

6. Livingston, S.A. \& Zieky, M.J. (1982). Passing scores: a manual for setting standards of performance on educational and occupational tests. Princeton, $\mathrm{NJ}$ : Educational Testing Service. p.12. [in English].

Стаття надійшла до редакції 18.08.2021

УДК 373.2.015.31:502/504

DOI:

Ірина Паласевич, кандидат педагогічних наук, доцент кафедри загальної педагогіки та дошкільної освіти Дрогобииького державного педагогічного університету імені Івана Франка

\title{
ПЕДАГОГІЧНІ УМОВИ ЕКОЛОГІЧНОГО ВИХОВАННЯ ДІТЕЙ СТАРШОГО ДОШКІЛЬНОГО ВІКУ
}

У статті проаналізовано сутність екологічного виховання дошкільнят, спрямованого на формування у них основ екологічної культури, елементів природоцілісного світогляду, ціннісно-змістової орієнтованості на екологічно доиільну діяльність і поведінку у довкіллі; охарактеризовано особливості екологічної вихованості дітей старшого дошкільного віку, шуо визначається рівнем їхніх знань і уявлень про норми та правила поведінки у природі, сформованістю навичок практичної природоохоронної діяльності у навколишньому середовищі, а також його збереження та примноження; визначено педагогічні умови підвищення ефективності екологічного виховання стариих дошкільнят.

Ключові слова: екологічне виховання; основи екологічної культури; екологічно доцільна діяльність $i$ поведінка у довкіллі; екологічне світобачення; емоційно-ціннісне ставлення до природи; педагогічні умови екологічного виховання; діти старшого дошкільного віку.

Jim. 15.

Iryna Palasevych, Ph.D.(Pedagogy), Associate Professor of the General Pedagogy and Preschool Education Department, Drohobych Ivan Franko State Pedagogical University

\section{PEDAGOGICAL CONDITIONS OF ECOLOGICAL EDUCATION OF THE CHILDREN OF SENIOR PRESCHOOL AGE}

The article analyzes the essence of ecological education of preschool children, aimed at forming in them the foundations of ecological culture, elements of a holistic worldview, value-based orientation on ecologically appropriate activities and behavior in the environment; the peculiarities of ecological upbringing of older preschool children are characterized, which is determined by the level of their knowledge and ideas about norms and rules of behavior in nature, the formation of skills of practical environmental activities in the environment, as well as its preservation and increase; emphasis is placed on the fact that older preschoolers experience the value (moral and 


\section{ПЕДАГОГІЧНІ УМОВИ ЕКОЛОГІЧНОГО ВИХОВАННЯ ДІТЕЙ СТАРШОГО ДОШКІЛЬНОГО ВІКУ}

aesthetic) aspects of interaction with the environment, constant attitudes of practical activities that determine behavioral programs for positioning themselves in the environment, contribute to the development of a special ecological worldview in children.

An emphasis is placed on the importance of direct communication of children with objects and phenomena of nature, the development of emotional and value attitudes towards them, aesthetic observation and a sense of beauty of the world, which is an important regulator of child behavior in the environment.

The pedagogical conditions for increasing the efficiency of environmental education of senior preschoolers are determined, namely: formation of their interest, positive motivation during the immersion of children in the developing ecological environment; systematic organization of observations in the environment, excursions, ecological trails, thematic days, ecological projects, which provide live contact of pupils with the natural environment, promote their elementary research activities; the need to ecologize different types of children's activities-cognitive, playful, art, speech, theatrical, musical, labor, etc.; cooperation of preschool educational institutions with families of preschool children in ecological education.

Keywords: ecological education; basics of ecological culture; environmentally safe activities and behavior in the environment; ecological worldview; emotional and value attitude to nature; pedagogical conditions of ecological education; children of senior preschool age.

П остановка проблеми. Бурхливий економічний та науковий розвиток XXI ст. спричинив значне погіршення екології на планеті. Забруднюються води Світового океану та повітряний басейн, деградують грунти, різко скорочується видова різноманітність флори та фауни, руйнуються унікальні природні комплекси, вичерпуються природні ресурси. Вберегти нашу Землю від екологічної катастрофи можна лише за умови глибокого усвідомлення нерозривності взаємозв'язків у тріаді “природа - людина суспільство”, власної відповідальності за збереження природних ресурсів.

Дошкільне дитинство $€$ найбільш сензитивним для усвідомлення себе невід'ємною частиною живої природи, своєї значущості у збереженні та примноженні її багатств. У Базовому компоненті дошкільної освіти зазначається, що до кінця дошкільного періоду у дитини мають бути сформовані елементи екологічного світорозуміння, основи природничо-екологічної компетенції, вихованості, позитивне емоційно-ціннісне ставлення до природи. Зміст цього документа орієнтує сучасних вихователів у доборі та проєктуванні відповідних завдань і технологій роботи 3 дітьми задля того, аби не стільки сформувати у них певну суму екологічних знань та елементарних уявлень про довкілля, скільки відкрити перед ними насамперед “науку життя", яка сприяла б розвитку почуття власної гідності у вихованців та відповідальності за свою поведінку, дії та вчинки в навколишньому середовищі $[1,13]$.

Аналіз останніх досліджень і публікацій. Проблемі екологічного виховання дошкільників присвячені наукові студії Н. Глухової, Н. Горопахи, Л. Іщенко [2], Т. Конюхової [3], Н. Кот [4], Н. Лисенко [5], В. Маршицької, Т. Науменко, С. Ніколаєвої, 3. Плохій [7-10],Н. Рижової,Р. Рославець, О. Соцької, Н. Яришевої та інших педагогів, у яких акцентовано на тому, що під час ознайомлення дітей дошкільного віку з природою важливо комплексно розв'язувати завдання екологічної освіти, виховання й екологічного розвитку, що сприятимуть опануванню ними широкого екологічного змісту, здатності усвідомлювати взаємозв'язки у природі, прогнозувати наслідки їх порушення, прагнути до екологічно доцільної діяльності. Здатність застосовувати екологічні знання, керуючись моральними нормами й цінностями, необхідними для екологічно доцільної діяльності, 3. Плохій визначає як екологічну компетентність $[10,116]$.

Відтак усвідомлення значущості окресленої проблеми спонукало до вибору теми пропонованої статті, метою якої є обгрунтування особливостей екологічного виховання дітей старшого дошкільного віку та визначення педагогічних умов, що забезпечують ефективність цього процесу.

Виклад основного матеріалу. Аналіз джерельної бази дає підстави стверджувати, що у науковій літературі сформувалися різні підходи до трактування сутності поняття "екологічне виховання”. Так, М. Фіцула визначає цю дефініцію як “...систематичну педагогічну діяльність, спрямовану на розвиток екологічної культури особистості" [14, 282]. На думку М. Мусієнко, екологічне виховання - це формування у людини свідомого сприйняття довкілля, почуття відповідальності за власну діяльність, пов'язану 3 перетворенням природного середовища, дбайливе ставлення до природи та розумне використання ії багатств [6, 119].

Екологічне виховання дітей дошкільного віку, як наголошує 3. Плохій, передбачає “. ...формування у дитини здатності та бажання діяти відповідно до екологічних знань, набутих у процесі навчання" $[10,117]$. Екологічні знання дослідниця трактує як ланку зв'язку особистості зі світом Природи, 
спосіб усвідомлення свого місця у ньому. Вони грунтуються на системі різних природничонаукових уявлень, екологічних понять. Екологічні знання виникають, функціонують та удосконалюються упродовж екологічно мотивованої діяльності [10, 118].

Дослідниця Н. Лисенко, своєю чергою, акцентує, що екологічне виховання невід’ємне від екологічної освіти й виокремлює два основні етапи першого - “....засвоєння дітьми екологічних знань та перетворення їх в елементи переконань як основне ядро свідомості" $[5,23]$.

Науковці одностайно вбачають мету екологічного виховання дошкільнят у формуванні основ екологічної культури, що передбачає усвідомлене правильне ставлення дитини до природи, розуміння себе як іiї частини і тісної залежності здоров'я й життя кожного з нас від стану довкілля $[3,66]$.

Екологічна культура особистості визначає стиль та спосіб ¥ї взаємодії з навколишнім середовищем, проєктує відповідну поведінку як підгрунтя екологічної діяльності. Основною компонентою екологічної культури постає екологічна свідомість, у структурі якої дослідники виокремлюють постійне спонукання до ініціативних дій щодо природи, а також розсудливе, відповідальне ставлення до неї. Екологічна свідомість, зі свого боку, реалізується через розум і почуття, мотиви, інтереси, позицію особистості, іiі вчинки та дії [7, 117].

Кінцевим результатом екологічної освіти й виховання $\epsilon$ екологічно вихована особистість. Екологічну вихованість Г. Пустовіт розглядає як один з основних показників індивідуальності, що характеризує поведінку і діяльність особистості в різноманітних ситуаціях міжособистісної взаємодії під час вивчення й охорони довкілля, в умінні оцінювати результати власної чи колективної діяльності, спрямованої на збереження природи $[11,60]$. Як твердить Л. Різник, екологічно вихованій особистості притаманні міцні переконання щодо необхідності охорони природи, а також уміння цілеспрямовано використовувати екологічні знання у повсякденні [12].

У дослідженні Л. Іщенко обгрунтовано чотири основні компоненти екологічної вихованості дітей старшого дошкільного віку: афективний, когнітивний, аксіологічний та праксеологічний. Так, перший із них насамперед обумовлений віковими особливостями й вирізняється емоційною безпосередністю, підвищеним інтересом до природного довкілля, живим відгуком дитини при зустрічі з прекрасним. Когнітивний компонент передбачає сформованість у старших дошкільнят певного рівня елементарних екологічних знань та уявлень, норм і правил поведінки у природі. Аксіологічний чинник полягає в розумінні цінності природи - як естетичної, так і практичної; умінні адекватно оцінити свої дії та вчинки, поведінку інших стосовно природи. Праксеологічний компонент включає формування у дітей позитивного ставлення до діяльності у природі, вияв турботи до рослинного та тваринного світу [2, 8-9].

Очевидно, важливим чинником, що визначає екологічну вихованість дошкільнят $є$ їхня поведінка у довкіллі; вміння іiі регулювати згідно iз законами навколишнього середовища, не завдаючи йому шкоди, не порушуючи його природних зв'язків. Екологічно доцільна поведінка визначається рівнем знань і уявлень дітей про норми та правила поведінки у природі, сформованістю навичокпрактичної природоохоронної діяльності у довкіллі, а також розумінням необхідності його збереження та примноження [4, 57]. Така поведінка дитини виражається у її вчинках щодо природи, постійному спонуканні до ініціативних природоохоронних дій, обмеженні вихованцем власних імпульсивних бажань задля нормального існування іншої живої істоти [9, 21].

Зрозуміло, що у молодшому дошкільному віці дитина діє ситуативно, часто не усвідомлюючи наслідки своїх дій та вчинків. Старші ж дошкільнята здатні пояснити свою поведінку, вони прагнуть діяти, як дорослі; потреба у схваленні спонукає їх дотримуватися встановлених етичних правил. На цьому віковому етапі урізноманітнюється й розширюється діяльність дітей, збільшується їхній досвід, активізуються пізнавальні мотиви, які поступово спрямовують їхню поведінку у природному довкіллі. До того ж старші дошкільнята усвідомлюють моральні норми та правила поведінки, адекватно оцінюють власні якості, розуміють значення своїх дій для оточення. Усе це, своєю чергою, спонукає дитину старшого дошкільного віку до позитивного вчинку заради іншої живої істоти з власної ініціативи, а не за вимогою дорослого. За систематичного та цілеспрямованого виховного впливу старший дошкільник здатен контролювати свої поведінкові прояви, власні дії та вчинки, дотримуватися моральних норм поведінки [10,83 - 84].

Цікавими є міркування 3. Плохій щодо типів діяльності дітей у природі та технологій їх освоєння. Дослідниця виокремлює прагматичний і непрагматичний різновиди. Мета першого типу діяльності полягає в отриманні практичного результату як “корисного продукту” для задоволення насамперед матеріальних потреб 
людини; непрагматична діяльність спрямована на задоволення їі духовних запитів. Вона (діяльність) може бути пізнавальною, естетичною, природоохоронною [10,73].

Пізнавальна діяльність у світі Природи має на меті отримання нової інформації, розвиток зацікавленості, позитивної мотивації до власне процесу пізнання; естетична - формування естетичного сприймання і спостережливості, естетичних почуттів та переживань; природоохоронна діяльність полягає у запобіганні негативним діям щодо конкретних об'єктів природи, їхніх середовищ, угруповань, екосистем найближчого природного оточення.

Найкращим особистісним критерієм високого рівня екологічної культури $\epsilon$, звісно, непрагматична взаємодія із природним довкіллям. Ця важлива особистісна якість, як зауважує 3. Плохій, формується за умови освоєння дітьми певних технологій діяльності. Так, до змісту естетичних технологій дослідниця залічує насамперед безпосереднє естетичне сприймання природи, “милування” об’єктами та явищами у середовищі їх існування. Естетичному освоєнню світу Природи сприяють образотворчомовленнєва діяльність, художнє фотографування, літературна творчість, декоративно-ужиткове мистецтво, музика, пластика. Усі види діяльності естетичної спрямованості передбачають здатність естетично сприймати об'єкт, естетично оцінювати його властивості та передавати їх за допомогою малюнка, аплікації, творчої розповіді, пластичних рухів, звуків тощо [10,74].

Щодо технологій пізнавальної діяльності у природі, то найпоширенішими 3 них $\epsilon$ спостереження та експериментування, педагогічно цінні за умови володіння дітьми вміннями планувати діяльність, фіксувати отримані результати, узагальнювати, робити висновки, мати уявлення про правила поведінки й безпеки. Пізнавальна інформація закріплюється й уточнюється під час ігрової, мовленнєвої, образотворчої діяльності [8].

Зв'язок дитини зі світом Природи формується шляхом турботливого ставлення до об'єктів, які потребують допомоги, природоохоронної пропаганди. Так, старші дошкільнята разом із дорослими можуть виготовляти для птахів годівниці, підгодовувати тварин узимку, висаджувати лікарські рослини тощо. Як підтверджує практика, природоохоронна діяльність має цінний виховних ефект, коли у дошкільнят сформоване ціннісне ставлення до навколишнього середовища, адже вона грунтується на власній екологічній активності дитини, а не на виконанні прохань чи вимог дорослого $[10,75]$.

Зауважимо, що безпосереднє спілкування дітей 3 об'єктами та явищами довкілля сприяє виникненню у них позитивних емоцій. Під час такої своєрідної взаємодії з об'єктами природи у дошкільнят формується емоційно-ціннісне ставлення до них. Упродовж їх сприймання, як наголошує Ж. Юзвак, можна виокремити два компоненти: емоційний (прояви радості, здивування, захоплення, прагнення привернути увагу до того чи того об'єкта, згадування про нього через певний час) та пізнавальний (естетична спостережливість, що виявляється у здатності самостійно виділяти об'єкт серед інших; уміння висловлювати певні судження про об'єкт та його властивості) $[15,51-52]$.

Формуючи в дітей гуманне ставлення до природи, на думку 3. Плохій, доцільно виходити 3 того, що вони є невід'ємною її частиною. Виявляючи співчуття до іншої живої істоти, визнаючи ії право на існування, вихованці стають добрішими, відповідальнішими, уважнішими [10,71].

Уважаємо, що сформувати гуманістичний світогляд дитини поза естетичною константою буття неможливо. Адже любов і повага до всього живого не виникає лише в межах споживання, а передбачає насамперед духовну цілісність, $є$ засобом розкриття сутнісних сил дитини.

До системи гуманістичного світогляду органічно вплітається екологічне світобачення це певною мірою цілісне уявлення дитини про природне довкілля, про саму себе та своє місце у ньому; це особливе розуміння світобудови, що грунтується на узагальнених знаннях про світ, на ідеальних переживаннях ціннісних (моральних та естетичних) аспектів взаємодії з природою; це сталі установки практичної діяльності, які зумовлюють поведінкові програми щодо позиціонування дитини у природі [13].

Екологічне світобачення дітей безпосередньо залежить від якості їхніх ціннісних орієнтацій на взаємозв'язок із природою. Турбуючись про належну культуру ставлення дошкільнят до природи, не слід нехтувати таким впливовим фактором екологізації їхньої свідомості, як формування естетичного сприйняття світу. Відчуття його краси може стати досить надійним регулятором поведінки дитини у природі, що $є$ важливим чинником естетичного, морального й екологічного виховання.

Висновки. Отож, процес екологічного виховання передбачає формування основ екологічної культури, структурними компонентами якої $є$ екологічні знання й уявлення, почуття й 
переживання, позитивне емоційно-ціннісне ставлення дітей до природи, що виникають у них під час взаємодії з нею, а також екологічно доцільна поведінка й діяльність у природі.

Екологічне виховання $є$ важливим напрямом роботи вихователів закладу дошкільної освіти, які мають стати для дітей не тільки носієм знань, а й прикладом для наслідування. Необхідно так зорганізувати діяльність дітей, щоб через їхні власні відкриття, розв'язання проблемних завдань, багатоманітні дії з природними об'єктами вони здобували нові знання про навколишній світ, усвідомлювали його красу й неповторність, берегли, охороняли та примножували його.

На нашу думку, ефективність екологічного виховання старших дошкільнят забезпечується реалізацією низки педагогічних умов, а саме: формування зацікавленості й позитивної мотивації під час занурення вихованців у розвивальне екологічне середовище; систематична організація спостережень у довкіллі, екскурсій, екологічних стежин, тематичних днів, екологічних проєктів, які налагоджують живий контакт дітей із природою, сприяючи їхній елементарній дослідницькопошуковій діяльності; необхідність екологізації різних видів діяльності дітей-пізнавальної, ігрової, образотворчої, мовленнєвої, театралізованої, музичної, трудової тощо; співпраця закладів дошкільної освіти з родинами вихованців в екологічному вихованні.

\section{ЛІТЕРАТУРА}

1. Базовий компонент дошкільної освіти України / наук. кер. : А.М. Богуш. Київ : Видавництво, 2012. 26 с.

2. Іщенко Л.В. Наступність у екологічному вихованні старших дошкільників і першокласників : автореф. дис. ... канд. пед. наук : 13.00.01 - теорія та історія педагогіки; Південноукр. держ. пед. ун-т ім. К.Д. Ушинського. Одеса, 1997. $17 \mathrm{c}$.

3. Конюхова Т.С. Характеристика загальних підходів до екологічної освіти й виховання дітей дошкільного віку на сучасному етапі. Освіта Донбасу. 2006. № 5 (118). С. $62-67$.

4. Кот Н.М. Про нові аспекти змісту екологічного виховання дошкільників. Педагогічні науки. Бердянськ, 2005. № 2. C. $54-59$.

5. Лисенко Н.В. Організація пошуково-дослідної роботи в дитячому садку. Київ : РУМК, 1990. 260 с.

6. Мусієнко М.М. Екологія. Тлумачний словник. Київ : Либідь, 2004. 376 с.

7. Плохій 3.П. Виховання екологічної культури дошкільників. Київ : Редакція журналу “Дошкільне виховання", 2002. $173 \mathrm{c}$.

8. Плохій 3.П. Природа як пізнавальна цінність. Дошкільне виховання. 2001. № 6. С. 7 -9.

9. Плохій 3.П. Формування екологічно мотивованої діяльності дошкільнят. Дошкільне виховання, 2005. № 7 . C. $19-21$.

Молодь і ринок №9 (195), 2021
10. Плохій 3.П. Формуємо екологічну компетентність молодшого дошкільника : навч.-метод. посіб. до Базової прогр. розв. дитини дошк. віку “Я у світі”. Київ : Світич, 2010. 144 с.

11. Пустовіт Г.П. Теоретико-методичні основи екологічної освіти і виховання учнів $1-9$ класів у позашкільних навчальних закладах. Київ - Луганськ : Альма-матер, 2004. 540 c.

12. Різник Л.М. Екологічне виховання за народними традиціями. Початкова школа, 1995. № 7. С. 20-26.

13. Тарасенко Г. Формування у дошкільників гуманно-особистісного ставлення до природи : аксіологічний аспект. Актуальні проблеми дошкілля : зб. наук. пр. / за ред. М. Чепіль. Дрогобич : РВВ ДДПУ ім. І. Франка, 2012. С. $13-20$.

14. Фіцула М.М. Педагогіка : навч. посіб. для студ. вищих пед. закладів освіти. Київ : Академія, 2000. 544 с.

15. Юзвак Ж. Естетичне сприймання : психологічний аспект. Початкова школа, 2000. № 12. C. $51-52$.

\section{REFERENCES}

1. Bazovyi komponent doshkilnoi osvity v Ukraini (2012). [The basic component of preschool education in Ukraine]. Kyiv, 26 p. [in Ukrainian].

2. Ishchenko, L.V. (1997). Nastupnist u ekolohichnomu vykhovanni starshykh doshkilnykiv i pershoklasnykiv [Continuity in ecological education of senior preschoolers and first-graders]. Extended abstract of candidate's thesis. Odessa, 17 p. [in Ukrainian].

3. Koniukhova, T. S. (2006). Kharakterystyka zahalnykh pidkhodiv do ekolohichnoi osvity y vykhovannia ditei doshkilnoho viku na suchasnomu etapi [Characteristics of general approaches to environmental education and upbringing of preschool children at the present stage]. Education of Donbass. No. 5 (118). pp. 62 - 67. [in Ukrainian].

4. Kot, N. M. (2005). Pro novi aspekty zmistu ekolohichnoho vykhovannia doshkilnykiv [On new aspects of the content of environmental education of preschoolers]. Pedagogical sciences. Berdyansk. No. 2. pp. 54 - 59. [in Ukrainian].

5. Lysenko, N. V. (1990). Orhanizatsiia poshukovodoslidnoi roboty $\mathrm{v}$ dytiachomu sadku. [Organization of research work in kindergarten]. Kyiv, 260 p. [in Ukrainian].

6. Musiienko, M.M. (2004). Ekolohiia. Tlumachnyi slovnyk [Ecology. Dictionary]. Kyiv, 376 p. [in Ukrainian].

7. Plokhii, Z. P. (2002). Vykhovannia ekolohichnoi kultury doshkilnykiv [Education of ecological culture of preschoolers]. Kyiv, 173 p. [in Ukrainian].

8. Plokhii, Z. P. (2001). Pryroda yak piznavalna tsinnist [Nature as a cognitive value]. Preschool education. No. 6. pp. 7 -9. [in Ukrainian].

9. Plokhii, Z. P. (2005). Formuvannia ekolohichno motyvovanoi diialnosti doshkilniat. [Formation of ecologically motivated activity of preschool children]. Preschool education. No. 7.pp. 19-21. [in Ukrainian].

10.Plokhii, Z. P. (2010). Formuiemo ekolohichnu kompetentnist molodshoho doshkilnyka [Form the ecological competence of the youngest preschooler]. Educational and methodical manual to the Basic 


\section{ІНДИВІДУАЛЬНА ОСВІТНЯ ТРАЕКТОРІЯ ЗДОБУВАЧІВ ВИЩОЇ ОСВІТИ: КОНТЕНТ-АНАЛІЗПОНЯТТЯ, ПРИНЦИПИПОБУДОВИ, ФОРМИТА МЕТОДИ РЕАЛІЗАЦЇ}

program of preschool child development "I am in the world". Kyiv, 144 p. [in Ukrainian].

11.Pustovit, H. P. (2004). Teoretyko-metodychni osnovy ekolohichnoi osvity i vykhovannia uchniv $1-9$ klasiv u pozashkilnykh navchalnykh zakladakh [Theoretical and methodological foundations of environmental education and upbringing of students $1-$ 9 classes in out-of-school educational institutions]. Kyiv - Luhansk, 540 p. [in Ukrainian].

12. Riznyk, L. M. (1995). Ekolohichne vykhovannia za narodnymy tradytsiiamy [Ecological education according to folk traditions]. Elementary school. No. 7.pp. 20-26. [in Ukrainian].
13. Tarasenko, H. (2012). Formuvannia u doshkilnykiv humanno-osobystisnoho stavlennia do pryrody : aksiolohichnyi aspect [Formation of humane and personal attitude to nature in preschoolers: axiological aspect]. Current problems of preschool. Drohobych, pp. 13-20. [in Ukrainian].

14. Fitsula, M. M. (2000). Pedahohika : navch. posib. dlia stud. vyshchykh ped. zakladiv osvity [Pedagogy : a textbook for students of higher pedagogical educational institutions]. Kyiv, 544 p. [in Ukrainian].

15. Iuzvak, Zh. (2000). Estetychne spryimannia : psykholohichnyi aspekt [Aesthetic perception : psychological aspect]. Elementary school. No. 12.pp. 51 -52. [in Ukrainian].

Стаття надійшла до редакції 11.08.2021

УДК 378.147.091.31

DOI:

Валентина Литвин, доктор філософї̈, викладач кафедри педагогіки, психології, початкової освіти та освітнього менеджменту Комунального закладу “Харківська гуманітарно-педагогічна академія” Харківської обласної ради

\section{ІНДИВІДУАЛЬНА ОСВІТНЯ ТРАЄКТОРІЯ ЗДОБУВАЧІВ ВИЩОЇ ОСВІТИ: КОНТЕНТ- АНАЛІЗ ПОНЯТТЯ, ПРИНЦИПИПОБУДОВИ, ФОРМИ ТА МЕТОДИ РЕАЛІЗАЦІЇ}

У статті здійснено контент-аналіз поняття “індивідуальна освітня траєкторія”, розкрито принципи ї̈ побудови, схарактеризовано форми та методи реалізаиї індивідуальної освітньої траєкторї̈ здобувачів вищої освіти. З'ясовано, щуо визнання права здобувачів вищої освіти на побудову індивідуальної освітньої траєкторії є одним із сучасних актуальних нововведень. Схарактеризовано специфіку побудови індивідуального навчального плану здобувачів вищьї освіти; розкрито права здобувачів вищзӧ освіти на вибір освітніх компонентів при самостійному формуванні певної частини індивідуального навчального плану; визначено специфіку визнання результатів навчання, отриманих у неформальній освіті та академічній мобільності.

Ключові слова: індивідуальна освітня траєкторія; студентоцентрований підхід; індивідуальний навчальний план; вибіркові освітні компоненти; неформальна освіта; мобільність.

Jim. 12.

Valentyna Lytvyn, Doctor of Sciences (Philosophy), Lecturer of the Pedagogy, Psychology, Primary Education and Education Management Department Municipal Establishment "Kharkiv Humanitarian-Pedagogical Academy”,

Kharkiv Regional Council

\section{INDIVIDUAL EDUCATIONAL TRACTORY OF HIGHER EDUCATION APPIICANTS: CONTENT-ANALYSIS OF THE CONCEPT, PRINCIPLES OF CONSTRUCTION, FORMS AND METHODS OF REALIZATION}

The article analyzes the content of the concept "individual educational trajectory", reveals the principles of its construction, describes the forms and methods of implementation of the individual educational trajectory of higher education. It has been found that the strategy of modern higher education is to provide opportunities for higher education students to discover and develop their creative potential. Recognition of the right of higher education seekers to build an individual educational trajectory is one of the current innovations. In this regard, the student-centered orientation and organization of the educational process acquires special relevance and value, which includes: taking into account the individual capabilities and needs of applicants for higher education; enabling their freedom to choose the components of educational programs; stimulating conscious and responsible design of individual educational trajectory by applicants for higher education. It is characterized that the modernization of the modern educational process involves a student-centered orientation, which means independence, comfort and individualization of learning, increasing the degree of freedom of learners regarding: their choice of educational components; non-formal education; training in domestic or foreign free economic zones 